Хомич Іванна

викладач кафедри вікової та педагогічної психології Рівненського державного гуманітарного університету https://orcid.org/ 0000-0001-8930-6572

DOI https://doi.org/10.35619/praprv.v1i16.230

\title{
КОНЦЕПТУАЛЬНІ ПІДХОДИ ДО ВИВЧЕННЯ ПРОБЛЕМИ НОРМАТИВНОСТІ У ПСИХОЛОГІЧНІЙ НАУЦІ
}

Анотація. У положеннях наукової статті автор аналізує концептуальні підходи до вивчення проблеми нормативності у вітчизняній $і$ зарубіжній психологічній науці та рівень дослідженості вказаної проблеми, зокрема, в аспекті психологічного аналізу нормативної поведінки особистості. Автор також здійснює уточнення та подальшу конкретизацію понятійного апарату дослідження, який включає дефініції базових категорій та понять роботи. В рамках статті здійснено аналіз характеру конгруентних зв'язків між нормативністю та нормою. В якості сутнісних атрибутивних характеристик норми, змістовно релевантних предмету дослідження - нормативній поведіниі, автор виокремлює: об'єктивність норми, тобто незалежність ї̈ від індивідуальної свідомості; низький ступінь усвідомлення; здатність здійснювати регулюючий вплив на поведінку; здатність організовувати поведінку в певному напрямку, тобто виступати в якості формуючого орієнтиру діï; властивість прогнозувати кінцевий результат дій.

Ключові слова: норма, нормативність, нормативна поведінка, сочіальна взаємодія, соціальні норми.

Постановка проблеми. Кардинальні соціоструктурні перетворення, які за роки реформ відбулися у багатьох сферах життя нашої держави, закономірно призвели до появи системної кризи українського суспільства. Ставши імперативом сьогодення, вона генерує нову для українців реальність - нормативний і правовий нігілізм, деформацію соціальнонормативних відносин, порушення нормативної узгодженості індивідуального і суспільного життя. Тому закономірним є зростання інтересу до питань, які пов’язані з гармонізацією системи нормативних відносин у суспільстві. Важливим у цьому контексті напрямом науково-психологічних досліджень $є$ вивчення нормативної поведінки особистості особливої форми її індивідуальної активності, спрямованої на засвоєння змісту соціальних норм та їх відтворення у формі суспільно прийнятих нормативних зразків поведінки.

Аналіз останніх досліджень. Метою нашого дослідження $є$ визначення концептуальних рамок розробки проблеми нормативності, зокрема, в аспекті психологічного аналізу нормативної поведінки особистості. Щодо завдань дослідження, то здійснимо уточнення та подальшу конкретизацію понятійного апарату, який включатиме дефініції базових категорій та понять нашої роботи. Традиційно наукова рефлексія проблеми нормативності здійснюється в рамках кількох дослідницьких підходів, кожен 3 яких використовує відповідний понятійний апарат, роблячи акцент лише на конкретному аспекті iii вивчення. Якщо прослідкувати «еволюцію» поглядів на становлення проблеми нормативності у просторі їі наукового аналізу, то стає очевидним, що він здійснювався багатьма дослідниками в рамках двох основних напрямків, для яких точкою відліку у розумінні та інтерпретації сутнісної природи нормативності виступає категорія «норми» (Пащенко, 2012).

Перший напрямок представлений в ранніх роботах культурологів, філософів, соціологів, педагогів та психологів (Бобнєва, 1978; Плахов, 2002) і пов’язаний здебільшого 3 аналізом загальних питань, зокрема, із загальним розумінням норми та їі ролі у процесі регулювання соціальної взаємодії. Другий напрямок, який представлений сучасними роботами, у своїй більшості виконаними у ключі соціально-психологічного та психолого- 
педагогічного аналізу (Корчакава, 2016; Пащенко, 2012; Лукашева, 2009), пов'язаний 3 розумінням норми та іiі ролі у процесі регулювання конкретних ситуацій соціальної взаємодії. Тому з метою подальшої конкретизації теоретичного концепту, що складає сутність концептуальних основ нашого дослідження, здійснимо більш розлогий аналіз характеру конгруентних зв'язків між нормативністю та нормою.

Спроби визначити дефініцію та конкретизувати змістові характеристики нормативності здійснювались як у вітчизняній, так і в зарубіжній літературі (Бобнєва, 1978; Леонгард, 1981; Ліпатов, 1996; Лисун, 2006; Лукашева, 2009, Маслоу, 2007; Пащенко, 2012). На підставі наявного в сучасній літературі базису уявлень про психологічну сутність нормативності приходимо до висновку, що дефінітивний статус даного поняття не $є$ в повній мірі визначеним. Це викликає плутанину при спробах його змістової операціоналізації у площині вирішення не стільки методологічних, скільки теоретикоприкладних задач. І хоча досвід використання поняття «нормативність» на сьогодні є доволі репрезентативним (Ліпатов, 1996; Лисун, 2006; Лукашева, 2009; Пащенко, 2012), проте все ще відсутнє інтегроване розуміння його сутнісного змісту. 3 одного боку, нормативність розуміють як форму соціального розвитку та об'єктивно необхідних способів суспільної взаємодії (Ліпатов, 1996; Лукашева, 2009), що в певній мірі дозволяє розглядати іiі як абстрактну категорію, а з іншого боку, - як прояв поведінкової активності, або сукупність актів дії, які відповідають абстрактно сформульованим суспільним правилам, що 3 очевидністю надає їй вже конкретного змісту (Пащенко, 2012). Такий дуалізм теоретичних уявлень щодо змісту нормативності є на сьогодні ще до кінця не вирішеним.

У дисертаційному дослідженні нормативності правових явищ Ліпатов обгрунтовує позицію, що нормативність виступає не тільки в якості форми буття соціальних інтересів, але і як процес формування і виділення цих способів існування соціальної реальності. Відповідно, нормативність у автора операціоналізується як значуща форма соціального розвитку (Ліпатов, 1996). В інтерпретації Лукашевої, яка розглядає питання нормативноціннісного виміру людського буття, нормативність виступає формою об'єктивно необхідних зв'язків та способів соціальної взаємодії (Лукашева, 2009). Актуальною в контексті нашого дослідження $є$ думка Заморської, для якої нормативність пов'язана зі здатністю здійснювати моделюючу дію для належної поведінки суб'єкта, виступаючи тим самим орієнтуючим і упорядковуючим іiі чинником (Заморська, 2011). Розвиваючи цю сентенцію, Ліпатов приходить до висновку, що якість нормативності можна визнати за широким спектром соціальних явищ, включаючи соціальні норми, суспільні відносини та свідомість, які можуть моделювати поведінку суб'єктів; тільки в цьому випадку нормативність об'єктивується у своїй вищій, найбільш абстрактній формі, а не в якості певного масштабу поведінки (Ліпатов, 1996). У ракурсі соціально-психологічної інтерпретації нормативність виступає в якості взаємообумовлених нормативних особистісних характеристик. Саме 3 цих позицій у своєму дисертаційному дослідженні Лисун доповнює традиційні рамки розуміння нормативності. Науковець описує даний термін як властивість свідомості, яка розвивається «за спіраллю» та операціоналізує його як сукупність взаємообумовлених нормативних якостей людини (воля, свобода, відповідальність), реалізація яких представляє собою органічний процес, спрямований на забезпечення цілісності іiі життя та діяльності. На думку автора, розвиток нормативності базується на принципі перманентних змін i підпорядковується організованим та цілеспрямованим механізмам передачі та засвоєння суспільного досвіду (Лисун, 2006).

Дещо відмінної позиції у розумінні сутнісного вияву нормативності притримується Пащенко, операціоналізуючи іiі в якості базової характеристики освоєння норми. Автор виходить з того, що норма об'єктивує свій характер у формі багаторівневої структури, кожний рівень якої (імпульсивний, польовий, рольовий, нормативний) відображає якість освоєння норми. Виділені ним нормативні рівні характеризують процес освоєння норми, детермінований необхідністю їх послідовного проходження. Кожний такий рівень характеризується своїми іманентними ознаками, здатність до виділення яких пов'язується 3 рівнем нормативного розвитку особистості. Фактично, позиція Пащенка у розумінні 
сутнісного вияву та змісту нормативності є більш ніж переконливою, зважаючи на те, що викладені сентенції знайшли своє емпіричне підтвердження (Пащенко, 2012). Виходячи 3 цього, нормативність можна інтерпретувати як характеристику особистості, яка відображає як процес освоєння соціальної норми, так і якість засвоєння соціально-нормативних приписів та виступає необхідною умовою її існування в онтогенезі.

На підставі узагальнення результатів аналізу сучасного стану розробки проблеми нормативності в аспекті вивчення сутнісних характеристик розвитку нормативної поведінки особистості стало можливим стверджувати про очевидний дефіцит теоретичних та концептуальних засобів для їі глибокого осмислення. 3 огляду на дискусійний характер розуміння змісту сутнісного вияву нормативності, вирішення означеної проблеми необхідно шукати у площині інтеграції наявних позицій психологів та представників суміжних дисциплін. В цьому випадку важливо розуміти, що об'єктивуючи сутнісний зміст нормативності, ми маємо розглядати його через призму суспільної, соціальної та особистісної взаємообумовленості. Іншими словами, нормативність слід розуміти як властивість суспільного, соціального та психологічного рівнів; як системну якість, яка 3 необхідністю виникає та об'єктивується у системі соціального контролю, компонентами якої виступають не тільки суспільство і групи, які генерують норми, не тільки самі норми, які регулюють відносини в даній системі, але й особистість, яка сприймає норми і реалізує їх у поведінці, а також здійснює зворотній вплив на групи і суспільство шляхом перетворення цих норм. Що в даному випадку не викликає застережень, так це розуміння того, що системоутворюючим компонентом такої системної якості як нормативність виступає норма.

Норма об'єктивно є точкою перетину багатьох суспільних, культурних, соціальних, психологічних процесів, тому іiі вивчення має міждисциплінарне значення. Проблема норми та нормативної поведінки вивчалась багатьма вітчизняними науковцями (Бобнєва, 1978; Пащенко, 2012; Плахов, 2002 та ін.), проте і до сьогодні в науці відсутнє інтегроване визначення норми. Слід відмітити, що вітчизняні та зарубіжні джерела фіксують високу контекстуальну поліваріантність терміну «норма», що дозволяе використовувати його у контексті опису широкого спектру іiі (норми) різновидів: статистичної, біологічної, індивідуальної, поведінкової, культурної, психічної, психологічної, соиіальної, правової, моральної, суспільної, групової, етнічної, духовно-релігійної, гендерної та ін. При першому наближенні у нас виникають обгрунтовані сумніви 3 приводу можливості універсальної категоризації норми, оскільки кожний ії різновид має свій спектр відтворення та у різних галузях знання має своє значення, що не може задовольняти широкий контекст іiі використання.

У своїй монографічній праці Тарасов відмічає, що у відношенні терміна «норма» існує два підходи щодо його розуміння. Для представників першого підходу норма виступає якістю, що має дві форми вияву - як природний стан деяких суб'єктів та як правило поведінки, пов'язане 3 волею людини, що виникає у процесі культурного розвитку i соціальної організації суспільства (Тарасов, 2001:123 та ін.). Для представників другого підходу норма об'єктивується як інституціолізована суспільством та інтерналізована індивідами основа соціального порядку (Плахов, 2002), яка освоюється в процесі їх соціалізації та забезпечуються механізмами соціального контролю. Також серед науковців поширеною є традиція розглядати норму, в одному випадку, як явище суб'єктивного характеру (суб'єктивний феномен), а в іншому - як феномен об'єктивного характеру (Тарасов, 2001; Плахов, 2002). Аналізуючи змістові аспекти використання поняття «норма», Плахов відмічає дві його передумови: перша - норма як одиниця вимірювання, яка «несе» кількісну характеристику пропорційності одиниць; друга - норма як специфічна соціальна якість, яка виділена з реальних процесів і зв'язків та існує не тільки в об'єктах реальності, а i в суспільній свідомості (Плахов, 2002; с. 6-9). Натомість, Маслоу критично ставиться до визначення норми як чогось середньостатистичного, ототожнюючи іiі з вищим ступенем досконалості, на яку тільки здатна людина (Маслоу, 2007). 3 позицій розуміння природи та функцій норми висловлюється Бобнєва. Аналізуючи суспільні відносини соціальної взаємодії, науковець вказує на об'єктивність норми, тобто незалежність від індивідуальної 
свідомості, як надзвичайно важливу іiі якість при вивченні нормативної проблематики (Бобнєва, 1978, с. 47). На думку ученої, у найбільш загальному розумінні нормативна регуляція означає, що індивідові або групі в цілому приписується належна поведінка, іiі форма, той чи інший спосіб досягнення мети, реалізації намірів; «задається» належний характер відносин і взаємодії людей у суспільстві, а реальна поведінка людей і відносин членів суспільства та різних соціальних груп програмуються відповідно до цих норм (Бобнєва, 1978). Схоже розуміння норми зустрічаємо у Яковлєва, який вказує на те, що нормальним вважається все, що є природним і правильним. Разом 3 тим, уявлення про «правильне» в силу соціальних та історичних обставин $є$ різними, умовними і відносними, відтак не може існувати єдиного його визначення. Науковець стверджує, що там, де позиції, установки та цінності особистості співпадають з позиціями, установками та цінностями оточуючого соціального середовища, слід говорити про існування «норми» у поведінці цієї особистості (Яковлєв, 1971). На підставі викладеного буде небезпідставним твердження про те, що норми, для того, щоб стати особистісними регуляторами поведінки людини, повинні трансформуватися в їі особистісні структури, а останні - стати їхнім джерелом. Ми можемо погодитись 3 позицією вище згаданих науковців в тій частині, що норма не тільки оцінює та орієнтує подібно до ідей, ідеалів, а й спрямовує на досягнення певного результату, інтересу. Дійсно, вплив норм на особистість має спрямовуючий характер.

Аналізуючи зміст норми, Братусь зазначає, що «... більш поширеним залишається для багатьох психологів та психіатрів розуміння норми як, по-перше, чогось середнього, усталеного, того, що не виділяється з маси, i, по-друге - більш пристосованого, адаптованого до певного середовища» (Братусь, 1988). Для Леонгарда, який вивчав природу акцентуйованої особистості, норма виступає певним стандартом поведінки в діапазоні прийнятних відхилень в той або інший бік (Леонгард, 1981). У своїй праці автор обгрунтовує точку зору, що, не дивлячись на доволі широкий діапазон нормального, прийнятного i дозволеного у суспільстві, все ж таки існує чимало людей з вираженими акцентуйованими особистісними рисами (Леонгард, 1981; с. 17-18], що в деякій мірі розмиває критерії розуміння норми (нормального). Схожої позиції у розумінні сутнісного змісту норми притримувався також відомий вітчизняний психолог Виготський, стверджуючи, що у дійсності не існує ніякої норми, але зустрічається безмежна кількість різних відхилень від неї, і часто складно сказати, де відхилення переходить ту межу, за якою починається область ненормального. Для вченого норма є більше абстрактною категорією, аніж чіткою характеристикою розмежування нормального від ненормального (Виготський, 2008:; с. 329).

На переконання Запорожця (1990) та багатьох інших вітчизняних науковців, з нормою потрібно пов'язувати не статистично середню особистість, а таку, яка в найбільш яскравій формі втілює сутнісні людські якості та характеристики. Виходячи 3 такої логіки, нормальною можна вважати поведінку, яка відповідає соціально прийнятим моральним нормам. I хоча дискусійною для нас являється теза згаданих вище дослідників щодо інваріативного по відношенню до особистості характеру норм, проте в частині забезпечення функції суспільного контролю за іiі поведінкою ми повністю розділяємо їхню позицію. Дійсно, норми об'єктивуються як система забезпечення контролю та впорядкованості взаємодії і взаємовідносин суб'єктів спільної діяльності. Більше того, норми виступають як відповідний механізм, що надає суб'єктам спільної діяльності можливість прогнозування і передбачення дій в рамках установлених правил та соціальних очікувань.

Висновки. Таким чином, змістовий аналіз дослідницьких підходів та позицій авторів у відношенні визначення поняття «норми» дозволяє нам стверджувати, що його концептуалізація здійснюється та грунтується переважно на розгляді парціальних ознак і функцій феномену нормативності. 3 огляду на це, попереднє узагальнення результатів аналізу сучасного стану розробки нормативної проблематики підвело нас до необхідності конкретизувати зміст поняття «норми» в контексті розуміння сутнісних (змістових, структурних, функціональних) особливостей детермінації нормативної поведінки. В якості сутнісних атрибутивних характеристик норми, змістовно релевантних предмету нашого дослідження - нормативній поведінці, у нас виступають: об'єктивність норми, тобто 
незалежність іiі від індивідуальної свідомості; низький ступінь усвідомлення; здатність здійснювати регулюючий вплив на поведінку; здатність організовувати поведінку в певному напрямку, тобто виступати в якості формуючого орієнтиру дії; властивість прогнозувати та передбачати кінцевий результат дій.

\section{СПИСОК ПОСИЛАНЬ}

Бобнева, М. (1978). Социальные нормы и регуляция поведения. Москва: Наука.

Братусь, Б. С. (1988). Аномалии личности. Москва: Мысль.

Выготский, Л. С. (2008). Педагогическая психология. Москва: АСТ: Астрель: Хранитель.

Заморська, Л. І. (2011). Соціальна нормативність: її особливості та взаємозв'язок з правом. Держава і право, 52, 14-19.

Запорожец, Л. А. (1990). Психологические особенности становления нравственного поведения у младших подростков. Психологические проблемы выявления и коррекции отклоняющегося поведения школьников, 18-26.

Корчакова, Н. В. Розуміння дітьми молодшого шкільного віку емоційного контексту просоціальної поведінки // Науковий вісник Херсонського держ. ун-ту. Серія : Психологічні науки. http://nbuv.gov.ua/UJRN/nvkhp_2016_4_22

Леонгард, К. (1981). Акцентуированные личности. Киев: Вища школа.

Липатов, Э. Г. (1996). Нормативность правовых явлений. (Автореф. дис. канд. юрид. наук.). Саратов.

Лысун, О. В. (2006). Нормативность сознания как условие и ресурс развития циивилизиии. (Автореф. дис. канд. философ. наук). Хабаровск.

Лукашева, Е. А. (2009). Человек, право, цииилизации. Нормативно-ценностное измерение. Москва: Норма.

Маслоу, А. (2007). Мотивация и личность. Санкт-Петербург: Питер.

Пащенко, А. К. (2012). Развитие нормативного поведения младиих школьников: структурно-диалектический подход. Saarbrucken: LAP LAMBERT Academic Publishing.

Плахов, В. Д. (2002). Социальные нормы и девиантное поведение. Юридическая мысль, 2 (8), 91-104.

Тарасов, Н. Н. (2001). Методологические проблемы юридической науки. Екатеринбург: Издательство гуманитарного университета (УрГЮА).

Яковлев, А. М. (1971). Преступность и социальная психология. Москва: Юридическая литература.

\section{REFERENCE}

Bobneva, M. (1978). Sotsyalnyye normy i reguliatsyia povedenyia [Social norms in regulation of behaviour]. Moskva: Nauka. [in Russian].

Bratus, B. S. (1988). Anomalyy lychnosty [Personality anomalies]. Moskva: Mysl. [in Russian].

Vygotskyi, L. S. (2008). Pedagogycheskaia psykhologyia [Pedagogical psychology]. Moskva: AST: Astrel: Khranytel. [in Russian].

Zamorska, L. I. (2011). Sotsialna normatyvnist: yii osoblyvosti ta vzaiemozviazok z pravom [Social normativity: its features and relationship with law]. Derzhava $i$ parvo, 52, 14-19. [in Ukrainian].

Zaporozhets, L. A. (1990). Psykhologycheskye osobennosty stanovlenyia nravstvennoho povedenyia $\mathrm{u}$ mladshykh podrostkov [Psychological features of formation of moral behaviour of younger adolescents] Psykhologycheskye problemy viyavlenyia y korrektsyy otkloniaiushchegosia povedenyia shkolnykov, 18-26. [in Russian].

Korchakova, N. V. Rozuminnia ditmy molodshoho shkilnoho viku emotsiinoho kontekstu prosotsialnoi povedinky [Understanding the emotional context of prosocial behavior by children at elementary school age] Naukovyi visnyk Khersonskoho derzh. un-tu. - Seriia : 


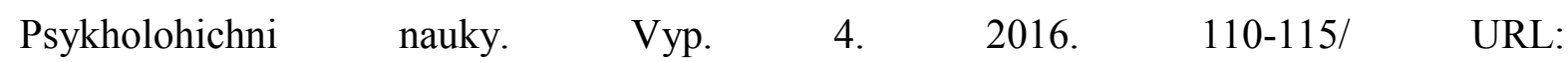

http://nbuv.gov.ua/UJRN/nvkhp 2016 422 [in Ukrainian].

Leongard, K. (1981). Aktsentuyrovanniye lychnosty [Accentuated personalities]. Kyev: Vyshcha shkola. [in Russian].

Lypatov, E. G. (1996). Normatyvnost pravovykh yavlenyi [Normativeness of legal phenomena]. (Avtoref. dys. kand. yuryd. nauk), Saratov. [in Russian].

Lisun, O. V. (2006). Normatyvnost soznanyia kak uslovye y resurs razvytyia tsyvylyzatsyy [Normativity of consciousness as a condition and resource for the development of civilization]. (Avtoref. dys. kand. fylosof. nauk), Khabarovsk. [in Russian].

Lukasheva, E. A. (2009). Chelovek, pravo, tsyvylyzatsyy. Normatyvno-tsennostnoe yzmerenye [Human, law, civilization. Normative and value dimension]. Moskva: Norma. [in Russian].

Maslou, A. (2007). Motyvatsyia y lychnost [Motivation and personality]. Sankt-Peterburg: Pyter. [in Russian].

Pashchenko, A. K. (2012). Razvytye normatyvnoho povedenyia mladshykh shkolnykov: strukturnodyalektycheskyi podkhod [Development of normative behaviour of primary schoolchildren: structural-dialectical approach]. Saarbrucken: LAP LAMBERT Academic Publishing. [in Russian].

Plakhov, V. D. (2002). Sotsyalnye normy y devyantnoe povedenye [Social norms and deviant behaviour]. Yurydycheskaia mysl, 2 (8), 91-104 [in Russian].

Tarasov, N. N. (2001). Metodologycheskye problembl yurydycheskoi nauky [Methodological problems of legal science]. Ekaterynburg: Yzd-vo humanyt. un-ta (UrHIuA). [in Russian].

Yakovlev, A. M. (1971). Prestupnost y sotsyalnaia psykhologyia [Crime and social psychology]. Moskva: Yuryd. lyt. [in Russian].

\title{
CONCEPTUAL APPROACHES THE PROBLEM OF NORMATIVITY IN PSYCHOLOGICAL SCIENCE
}

Ivanna Khomych

Lecturer at the Department of Developmental and Pedagogical Psychology, Rivne State University of Humanities https://orcid.org/ 0000-0001-8930-6572

DOI https://doi.org/10.35619/praprv.v1i16.230

\begin{abstract}
The article deals with the analysis of conceptual approaches to the problem of normativity in Ukrainian and foreign psychological science and the level of research of this problem, in particular, in the aspect of psychological analysis of the normative behaviour of individual. The author also clarifies and further concretizes the conceptual apparatus of the study, which includes definitions of basic categories and concepts of work. The article analyses the nature of congruent relationships between normativity and norm. It is emphasized that norms are objectified as a system of control and orderliness of interaction and relationships of the subjects of joint activities. Moreover, norms are an appropriate mechanism that provides the subjects of joint activities with the ability to predict and anticipate actions within established rules and social expectations.

The quality of normativity can be interpreted by a wide range of social phenomena, including social norms, social relations and consciousness, which can model the behaviour of subjects; only in this case normativity is objectified in its highest, most abstract form, and not as a certain scale of behaviour. As the essential attributive characteristics of the norm, meaningfully relevant to the subject of research - normative behaviour, the author identifies: the objectivity of the norm, i.e. its independence from individual consciousness; low level of awareness; the ability to exert a regulatory influence on behaviour; the ability to organize behaviour in a certain direction, i.e. to act as a formative guideline for action; the ability to predict the final result of actions.
\end{abstract}

Key words: norm, normativity, normative behaviour, social interaction, social norms.

Стаття надійшла до редакиї̈ 02.04.2021 p 